\title{
Evacuation and Repatriation Amidst COVID-19 Pandemic
}

\author{
Joseph Kawuki ${ }^{1,2 *}$, Shireen Salome Papabathini ${ }^{2}$, Nathan Obore ${ }^{2}$, Upama Ghimire ${ }^{2}$ \\ ${ }^{I}$ Centre for Health Behaviours Research, Jockey Club School of Public Health and Primary Care, Faculty of Medicine, The Chinese \\ University of Hong Kong, Hong Kong- SAR, China. \\ ${ }^{2}$ Key Laboratory of Environmental Medicine Engineering, Ministry of Education, Global Health, School of Public Health, Southeast \\ University, Nanjing, 210009, Jiangsu Province, China.
}

Received 23 February 2021; Revised 17 May 2021; Accepted 18 June 2021; Published 22 June 2021

\begin{abstract}
During the COVID-19 pandemic, evacuation and repatriation of nationals have been done by many countries. However, this has posed several socio-economic and public health issues that are worth exploring. This commentary, therefore, aims at exploring the impact of evacuation and repatriation amidst the COVID-19 pandemic. Evacuation and repatriation helped to alleviate the psycho-social effects of the pandemic on foreign nationals, and also creates a sense of relief for host nations due to the reduced stress related to caring for a potentially larger number of people. It also contributed to the enhancement of the healthcare systems of several countries. However, evacuation and repatriation have contributed to the importation of the virus into various countries. It presents significant logistic and economic challenges as it requires trained personnel and equipment. Therefore, there is a need for proper planning, financing and supervision to avoid possible importation of the virus during the expedition. In addition, community awareness regarding returnees is essential to prevent social discrimination and stigma.
\end{abstract}

Keywords: COVID-19; Evacuation; Repatriation; Returnees.

\section{Introduction}

Coronavirus disease 2019 (COVID-19) which was first reported in Wuhan, Hubei Province, in early December 2019 rapidly spread to other provinces in China and later to other countries through the infected travellers [1]. As a mitigation strategy, China issued a travel ban and quarantine on Wuhan and Hubei Province on 23rd January 2020 [2]. Initially, given the strict lockdown, and the continued growth of the outbreak in Hubei, several countries opted to evacuate their citizens and diplomatic staff from the area. The evacuation was done mainly through chartered flights arranged by the home countries, which required prior clearance by the Chinese authorities [3].

However, after the spread of COVID-19 to other countries and being declared a pandemic [4], evacuations were also made from other countries, especially those with a high spread of the virus. Notably, China also evacuated its citizens from some countries [5, 6]. The countries that initially evacuated their citizens included Japan, the USA, Australia, India, France, Germany, Thailand, among others [3]. Among African countries, South Africa, Morocco, Algeria, Nigeria, among others, have also repatriated their citizens from other countries. As a means of controlling the pandemic, several countries declared nationwide lockdowns, further giving rise to more repatriations worldwide. As of 05th August 2020, India statistically had the highest number of repatriated citizens (over 250,000), followed by the Philippines, USA, among others [7, 8]. During the COVID-19 evacuation and repatriation processes, the dominant

* Corresponding author: joseks256@gmail.com

doi http://dx.doi.org/10.28991/SciMedJ-2021-03-SI-7

$>$ This is an open access article under the CC-BY license (https://creativecommons.org/licenses/by/4.0/).

(C) Authors retain all copyrights. 
categories of people noted have been students, expatriates, and tourists aboard Cruise ships, the most famous being the Diamond Princess [9]. Nevertheless, various countries around the world opted not to repatriate their citizens because of several reasons, including insufficient medical experience and facilities at home [3].

Amidst the COVID-19 pandemic, evacuation and repatriation of nationals have been opted for due to a number of safety reasons. However, repatriation has posed several socio-economic and public health issues that are worth noting. Nonetheless, there is currently a dearth of literature that explicitly explored the dynamics of repatriation and evacuation amidst the ongoing COVID-19 pandemic. This article, therefore, aims at exploring the impact (in terms of pro and cons) of evacuation and repatriation amidst the COVID-19 pandemic. The highlights of this perspective could be vital in the appropriate implementation of the evacuation and repatriation exercise in current and future pandemics.

This commentary entails literature searched from key databases that included; Google Scholar, Web of Science and PubMed. Articles relevant to the topic were identified using keywords such as; "COVID-19 evacuation", COVID-19 repatriation", "COVID-19 returnees", "COVID-19 returning travellers", and "repatriated passengers" amongst others. In addition, valuable information was also obtained from key media websites.

\section{Why Were Evacuation and Repatriation Necessary?}

After China announced the lockdown of Wuhan and other cities, the world and experts were skeptical. All the panic-stricken citizens of China and foreigners stayed in their houses waiting for the nightmare to be over. Being in a foreign land, many people during this lockdown period lived in some form of fear, stress, frustration, depression, anxiety, among others due to the restricted movement [10]. The evacuation was a good measure taken to ease the psychological effects of COVID-19 lockdown among foreigners, who were homesick, those that felt discriminated, who had emergencies, pregnant women, students, stranded tourists, laid-off workers, those that lost their loved ones and those who preferred to face the pandemic in their country surrounded by their families and friends [3, 11].

At the initial stages of the pandemic, there was limited access to food, water and other necessities, and since the majority of people living abroad were students, it caused further distress worldwide [11]. Families around the world were panic-stricken, causing chaos and distress in the news and social media asking for help from their government authorities [12]. Evacuation or repatriation, therefore, helped to ease the families concerns and calmed down any possible tension created by this situation.

Furthermore, evacuation and repatriation have helped build the citizens' trust in their leaders. They were able to ensure the safe return of the citizens proving their efficiency in handling issues of their citizens. This has been achieved through securing evacuation flights, providing quarantine facilities as well as good communication and reassurance during the entire process $[13,14]$.

Evacuation and repatriation have also enabled some countries to enhance their health care systems through upscaling of quarantine centres, Intensive Care Units, training of doctors, among others in preparation for handling returnees $[15,16]$. Besides, it also creates a sense of relief for the host nations since it reduces the stress related to caring for a potentially more substantial number of people [17].

\section{The downside of COVID-19 Evacuation and Repatriation}

Despite the benefits of evacuation and repatriation, there are also several pitfalls worth noting. Due to the inadequate knowledge of this new virus, many asymptomatic patients have travelled back to their countries, causing the virus to spread worldwide. Although COVID-19 screening is done prior to evacuation and repatriation, many countries have reported positive COVID-19 returnees in these flights, thus posing a threat to their citizens and spreading the virus nationwide [1,3]. Many countries, such as the USA, Thailand, Australia, and Japan, among others, have reported imported cases through evacuation and repatriation flights [3].

Evacuation and repatriation also present immense logistical and economic challenges to both travellers and those involved in transporting them. Some of the logistical challenges include the issuance of special visas and travel arrangements for repatriation, making transportation available and gazettal of quarantine facilities for thousands of returnees [12]. In addition, the expedition involves trained staff, use of personal protective equipment and materials, supplying food according to dietary requirements, water and waste management capacity, among others [18]. These are expensive undertakings that can pose a huge economic challenge if not taken into consideration.

In addition, quarantine facility management is a big challenge as countries have to come up with strategies and targets in their capacity to manage the quarantine effectively. It has to be planned with thorough health checkups and supervision, which requires a lot of finances and human resource. Several countries opt for public facilities such as stadiums, schools, among others as quarantine options as well as private arrangements in hotels [3, 19]. This presents returnees with the added burden of having to pay for their quarantine fees. 
During the current pandemic, travellers onboard ships and flights are classified as individuals with high-risk exposure to COVID-19 [20, 21]. On top of this, the complex specific health guidelines for crew members are particularly taxing [22]. Furthermore, air travel restrictions during the pandemic pose an additional challenge to repatriation efforts as the prices for available flight tickets skyrocket [23]. Regarding travel by ship, Port health authorities face unprecedented challenges in terms of costs and uncertainties about arrangements and responsibilities if cases of COVID-19 are detected on ships. ${ }^{9}$ International Health Regulations (2005) require that each country port must have the capacity to apply or supervise health measures in response to a public health emergency of international concern [24].

Even after returnees successfully complete the recommended 14 days quarantine period, there is social stigma faced by quarantine individuals. In some communities, returnees have faced social exclusion, stereotyping, fingerpointing, mockery, and insults [25]. In addition, the healthcare workers monitoring the returnees have reported facing discrimination and stigma [26]. COVID-19 related social stigma and discrimination have implications, especially for children's social relationships at the community level, and it contributes to significant psychological distress among repatriated individuals [27]. Stigma-reduction strategies and interventions in communities receiving returnees should address both drivers like lack of knowledge or misinformation and facilitators like institutional practices, unfavourable health policies. Lessons can be taken from HIV-related stigma research which reveals that multiple stigma dimensions can negatively impact health-seeking practices and outcomes [28].

Evacuation may also increase the burden on the healthcare systems of poorly prepared countries. Public health authorities in some countries are already overburdened with efforts to contain community transmission and are possibly unable to deal with the potential risk of importation of more COVID-19 cases directly linked to evacuations and repatriation $[15,16]$.

\section{Conclusion}

This perspective provides information regarding the pros and cons of evacuation and repatriation during the pandemic of COVID-19. It alleviated the psycho-social effects of the pandemic on foreign nationals. Furthermore, it has, to some extent, enhanced the health care systems of several countries. However, evacuation and repatriation contributed to the spread of the virus, and it is associated with immense logistic and economic challenges. Besides, management of quarantine facilities and associated stigma of the returnees are notable issues regarding repatriation.

Therefore, there is a need for proper planning and financing of evacuation and repatriation expeditions. This should take into account the infection control and prevention protocols, which also includes standard operating procedures for departing travellers and for those in transit to avoid any possible importation of the virus. In addition, community awareness regarding returnees from COVID-19 affected areas to prevent social discrimination and stigma is essential.

\section{Declarations}

\subsection{Author Contributions}

Conceptualization, J.K. and S.S.P.; writing—original draft preparation, O.N., J.K. and U.G.; writing-review and editing, J.K., S.S.P., O.N. and U.G. All authors have read and agreed to the published version of the manuscript.

\subsection{Funding}

The authors received no financial support for the research, authorship, and/or publication of this article.

\subsection{Ethical Approval}

This commentary contains no experiments on humans and animals, so ethical approval not required.

\subsection{Data Availability Statement}

No new data were created or analyzed in this study. Data sharing is not applicable to this article.

\subsection{Conflict of Interest}

The authors declare that they have no known competing financial interests or personal relationships that could have appeared to influence the work reported in this paper.

\section{References}

[1] Hoehl, S., Rabenau, H., Berger, A., Kortenbusch, M., Cinatl, J., Bojkova, D., ... Ciesek, S. (2020). Evidence of SARS-CoV-2 Infection in Returning Travelers from Wuhan, China. New England Journal of Medicine, 382(13), 1278-1280. doi:10.1056/nejmc2001899. 
[2] Luo, G., McHenry, M. L., \& Letterio, J. J. (2020). Estimating the prevalence and risk of COVID-19 among international travelers and evacuees of Wuhan through modeling and case reports. PLOS One, 15(6), e0234955. doi:10.1371/journal.pone.0234955.

[3] Şencan, İ., \& Kuzi, S. (2020). Global threat of COVID 19 and evacuation of the citizens of different countries. Turkish Journal of Medical Sciences, 50(SI-1), 534-543. doi:10.3906/sag-2004-21.

[4] Cucinotta, D., \& Vanelli, M. (2020). WHO declares COVID-19 a pandemic. Acta Bio Medica: Atenei Parmensis, 91(1), 157. doi:10.23750/abm.v91i1.9397.

[5]Tuoitre News. (2020). Vietnam to fly last Wuhan visitors home. Available online: https://tuoitrenews.vn/news/society/20200127/vietnam-to-fly-last-wuhan-visitors-home/52741.html (accessed on August 2020).

[6] CGTN. (2020). 164 Chinese evacuees from Iran test negative after arriving in Chengdu. Available online: https://news.cgtn.com/news/2020-03-12/164-Chinese-evacuees-from-Iran-test-negative-after-arriving-in-ChengduON8G7Rj9v2/index.html (accessed on August 2020).

[7] ANI News (2020). India to launch largest overseas evacuation since Independence to bring back 1.92 lakh stranded nationals. Available online: https://aninews.in/news/world/asia/over-250-lakh-indians-evacuated-from-abroad-under-vande-bharatmission20200618184906/?amp=1 (accessed on August 2020).

[8] Goldstein, M. (2020). US State Department Brings Home More Than 85,000 Americans In Coronavirus Crisis. Forbes. Available online: https://www.forbes.com/sites/michaelgoldstein/2020/04/10/us-state-department-brings-home-more-than50000-americans-in-coronavirus-crisis/ (accessed on August 2020).

[9] Moriarty, L. F., Plucinski, M. M., Marston, B. J., Kurbatova, E. V., Knust, B., Murray, E. L., ... Kobayashi, M. (2020). Public Health Responses to COVID-19 Outbreaks on Cruise Ships - Worldwide, February-March 2020. MMWR. Morbidity and Mortality Weekly Report, 69(12), 347-352. doi:10.15585/mmwr.mm6912e3.

[10] Venkatesh, A., \& Edirappuli, S. (2020). Social distancing in covid-19: what are the mental health implications? BMJ, m1379. doi:10.1136/bmj.m1379.

[11] The New Indian Express. (2020). Coronavirus: Stranded Indians in US ask India to operate more evacuation flights. Available online: https://www.newindianexpress.com/world/2020/may/18/coronavirus-stranded-indians-in-us-ask-india-to-operate-moreevacuation-flights-2144976.html (accessed on June 2020).

[12] Rajbhandari, B., Phuyal, N., Shrestha, B., \& Thapa, M. (2020). Air Medical Evacuation of Nepalese Citizen during Epidemic of COVID-19 from Wuhan to Nepal. Journal of Nepal Medical Association, 58(222). doi:10.31729/jnma.4857.

[13] News18 India. (2020). Those Stranded in Australia Can be Back After Flights Resume Ops, Says Indian Envoy, Assures All Help via Hotline. Available online: https://www.news18.com/news/india/those-stranded-in-australia-can-be-back-after-flightsresume-ops-says-indian-envoy-assures-all-help-via-hotline-2589035.html (accessed on June 2020).

[14] Department of International Relations and Cooperation, South Africa. (2020). Minister Naledi Pandor: Repatriation of South Africans stranded abroad during COVID-19 Coronavirus lockdown. Available online: -https://www.gov.za/speeches/ministernaledi-pandor-repatriation-south-africans-stranded-abroad-during-covid-19 (accessed on June 2020).

[15] Hopman, J., Allegranzi, B., \& Mehtar, S. (2020). Managing COVID-19 in Low- and Middle-Income Countries. JAMA, 323(16), 1549. doi:10.1001/jama.2020.4169.

[16] Gilbert, M., Pullano, G., Pinotti, F., Valdano, E., Poletto, C., Boëlle, P.-Y., ... Colizza, V. (2020). Preparedness and vulnerability of African countries against importations of COVID-19: a modelling study. The Lancet, 395(10227), 871-877. doi:10.1016/s0140-6736(20)30411-6.

[17] Withers Worldwide. (2020). IRS issues relief to foreigners stranded in the United States due to coronavirus. Available online: https://www.withersworldwide.com/en-gb/insight/irs-issues-relief-to-foreigners-stranded-in-the-united-states-due-to-coronavirus (accessed on June 2020).

[18] Klemeš, J. J., Fan, Y. V., Tan, R. R., \& Jiang, P. (2020). Minimising the present and future plastic waste, energy and environmental footprints related to COVID-19. Renewable and Sustainable Energy Reviews, 127, 109883. doi:10.1016/j.rser.2020.109883.

[19] Tisha, T. (2020). See how sports stadiums have transformed to help pandemic relief efforts. National Geography. Available online: https://www.nationalgeographic.com/history/2020/05/sports-stadiums-transformed-help-pandemic-reliefefforts/ (accessed on July 2020).

[20] Hertzberg, V. S., Weiss, H., Elon, L., Si, W., \& Norris, S. L. (2018). Behaviors, movements, and transmission of dropletmediated respiratory diseases during transcontinental airline flights. Proceedings of the National Academy of Sciences, 115(14), 3623-3627. doi:10.1073/pnas.1711611115. 
[21] Teherán, A. A., Camero, G., Prado, R., Moreno, B., Trujillo, H., Ramírez, R. A., .. Ramírez, J. D. (2020). Presumptive asymptomatic COVID-19 carriers' estimation and expected person-to-person spreading among repatriated passengers returning from China. Travel Medicine and Infectious Disease, 37, 101688. doi:10.1016/j.tmaid.2020.101688.

[22] World Health Organization. (2020). Coronavirus disease 2019 (COVID-19): situation report, 47. Available online: https://apps.who.int/iris/bitstream/handle/10665/331444/nCoVsitrep07Mar2020-eng.pdf (accessed on July 2020).

[23]Al Root. (2020). Coronavirus Is Causing Airfares to Rise. Barron's. Available online: https://www.barrons.com/articles/airfarebargains-coronavirus-cruises-cheap-51589549611 (accessed on August 2020).

[24]World Health Organization International Health Regulations (2005), 3rd ed. Geneva, 2016. Available online: https://www.who.int/publications/i/item/9789241580496 (accessed on July 2020).

[25] Adom, D., \& Adu Mensah, J. (2020). The Psychological Distress and Mental Health Disorders from COVID-19 Stigmatization in Ghana. SSRN Electronic Journal. doi:10.2139/ssrn.3599756.

[26] Shigemura, J., \& Kurosawa, M. (2020). Mental health impact of the COVID-19 pandemic in Japan. Psychological Trauma: Theory, Research, Practice, and Policy, 12(5), 478-479. doi:10.1037/tra0000803.

[27] Imran, N., Aamer, I., Sharif, M. I., Bodla, Z. H., \& Naveed, S. (2020). Psychological burden of quarantine in children and adolescents: A rapid systematic review and proposed solutions. Pakistan Journal of Medical Sciences, 36(5). doi:10.12669/pjms.36.5.3088.

[28] Logie, C. H., \& Turan, J. M. (2020). How Do We Balance Tensions Between COVID-19 Public Health Responses and Stigma Mitigation? Learning from HIV Research. AIDS and Behavior, 24(7), 2003-2006. doi:10.1007/s10461-020-02856-8. 